\title{
The Use of Credit by Rice Farmers in Takeo
}

\author{
Kem Sothorn
}

\section{INTRODUCTION}

Farmers' lack of access to both working and investment capital is considered one of the major factors hindering the transition from low-input agricultural systems to more productive commercial ones (ACI 2005). Rice productivity in Cambodia is significantly constrained by low application of agricultural inputs, notably fertiliser, mechanisation, and irrigation (ACI 2005; World Bank 2007). Improving access to rural credit would be a significant step forward for smallholder agricultural development in the country. While there has been a boom in microfinance in Cambodia (CMA 2011), the impact on smallholder farmers remains limited, mainly due to the risks posed by insecure land tenure and uncertain returns to on-farm investment. Understanding the pattern of credit access and the way it affects rice farmers' borrowing and investment decisions could usefully inform policy options to improve the viability of rural credit delivery.

The hypothesis of this study was that ready access to credit raises rice farmers' productivity and farm income, thus improving the well-being and reducing the vulnerability of rural households. The study sought to (a) understand the patterns and characteristics of credit access of different farmers, (b) investigate the impact of credit on farmers' production and

K. Sothorn $(\bowtie)$

Parliamentary Institute of Cambodia, Phnom Penh, Cambodia

(C) The Author(s) 2020

309

R. Cramb (ed.), White Gold: The Commercialisation of Rice

Farming in the Lower Mekong Basin, https://doi.org/10.1007/978-981-15-0998-8_15 
livelihood systems, (c) identify challenges and opportunities for successful credit utilisation, and (d) provide options for improving credit access and promoting successful farm credit utilisation.

Qualitative research was undertaken in Takeo Province. The villages chosen for the study represented three rice production systems: rainfed wet-season (WS) rice, WS rice with supplementary irrigation, and irrigated dry-season (DS) rice. Five group interviews were undertaken with three types of rice farmers: subsistence farmers, semi-commercial farmers, and commercial farmers. The major themes for the group interviews were: the pattern of credit access, the impact of loans on productivity and livelihoods, and the challenges faced in accessing loans. Key informant interviews were undertaken with representatives of five major microfinance institutions (MFIs) in Takeo-CREDIT, AMRET, Sathapana, Thaneakea Phum, and Vision Fund. The interviews focused on constraints and opportunities for expanding credit, the institutional arrangements and policy environment for MFI operations, and trends in the development of the rural credit sector. Secondary data and statistics were collected from the Cambodia Microfinance Association (CMA), provincial development statistics, and previous research reports.

In this chapter, an overview of the credit sector in Cambodia is presented, with particular focus on the evolution of policy and outreach; the findings of the survey are discussed, including an analysis of the challenges and opportunities for credit use by subsistence, semi-commercial, and commercial rice farmers; and policy options and research gaps are identified.

\section{Overview of Credit Development in Cambodia}

Informal credit systems have long been an important part of rural livelihoods (Phlong 2009). Informal credit draws on a culture of reciprocity and risk-sharing within kinship groups and the residential community or village and is still widely practised. Some forms of informal credit such as village banks, savings-based microfinance, and self-help groups are vibrant forms of economic exchange, often initiated by NGO-sponsored community development programmes. These sources of finance are limited in coverage and provide relatively little capital. In most cases they cannot meet the demand for investment. Many of these community-based organisations (CBOs) simply dissolved after the project was completed. The limited capacity of informal credit systems has led to efforts to improve access to capital from formal credit institutions. 
Most formal credit in Cambodia has emerged from non-profit microfinance projects initiated to fill the void left by the virtually non-existent rural banking sector. According to CMA (2011), the sector has gone through three major stages of development (Table 15.1). A number of reforms have been made to improve the institutional environment for the development of microfinance, resulting in a steady increase in the number of licenced MFIs and registered micro-credit NGOs.

The Asian Development Bank estimated that the demand for rural finance in Cambodia was around USD 120-130 million per annum in 2000 (ADB 2001). By 2011 there were 29 MFIs and 1 commercial bank providing financial services in 24 provinces, covering 59,458 villages and 1.1 million borrowers with outstanding loans of USD 572.7 million, more than four times the ADB's estimate (Fig. 15.1). By the first quarter of 2017, CMA reported 61 MFIs with 1.9 million borrowers and outstanding loans of USD 3328 million (CMA 2017), a further sixfold increase.

Even though the number of villages covered by MFIs in 2011 was five times higher than the total number of villages in the country (due to multiple MFIs working in a given village), this does not mean that all rural communities had access to financial services. Rather, it reflects that MFIs tended to concentrate in densely populated areas and in economically active villages (Figs. 15.2 and 15.3). Hence, the number of MFIs in a

Table 15.1 Evolution of formal credit sector in Cambodia since 1995

\begin{tabular}{|c|c|}
\hline Period & Features \\
\hline $\begin{array}{l}1995- \\
2000\end{array}$ & $\begin{array}{l}\text { Government Support; Institutionalisation } \\
\text { - Credit Committee for Rural Development (CCRD) established in } 1995 \\
\text { - National Bank of Cambodia (NBC) set up Supervision Office of the } \\
\text { Decentralisation of Banking Systems Bureau in } 1997\end{array}$ \\
\hline $\begin{array}{l}2000- \\
2005\end{array}$ & $\begin{array}{l}\text { Commercialisation } \\
\text { - The government adopted a two-tier system under the Law on Banking } \\
\text { and Financial Institutions in } 1999 \\
\text { - Reform of banking system in } 2000 \\
\text { - Number of microfinance institutions (MFIs) increases from } 3 \text { to } 15 \\
\text { - Eight decrees issued in } 2005 \text { to enforce registration and licencing of MFIs }\end{array}$ \\
\hline $2005-$ & $\begin{array}{l}\text { An Integral Economic Player } \\
\text { - Credit information system introduced in } 2006 \text { to collect and share } \\
\text { negative information from commercial banks } \\
\text { - Cambodia Microfinance Association (CMA) established in } 2007 \\
\text { - Decree on Licencing Microfinance Deposit Taking Institutions issued by } \\
\quad \text { NBC in } 2007\end{array}$ \\
\hline
\end{tabular}


$2,500,000$

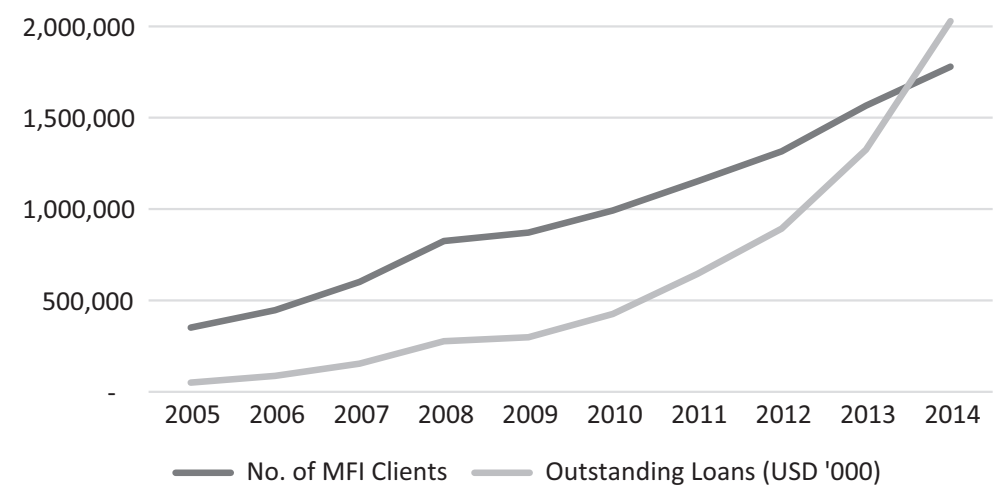

Fig. 15.1 Growth of MFI clients and loans in Cambodia, 2005-2014. (Source: CMA 2015)

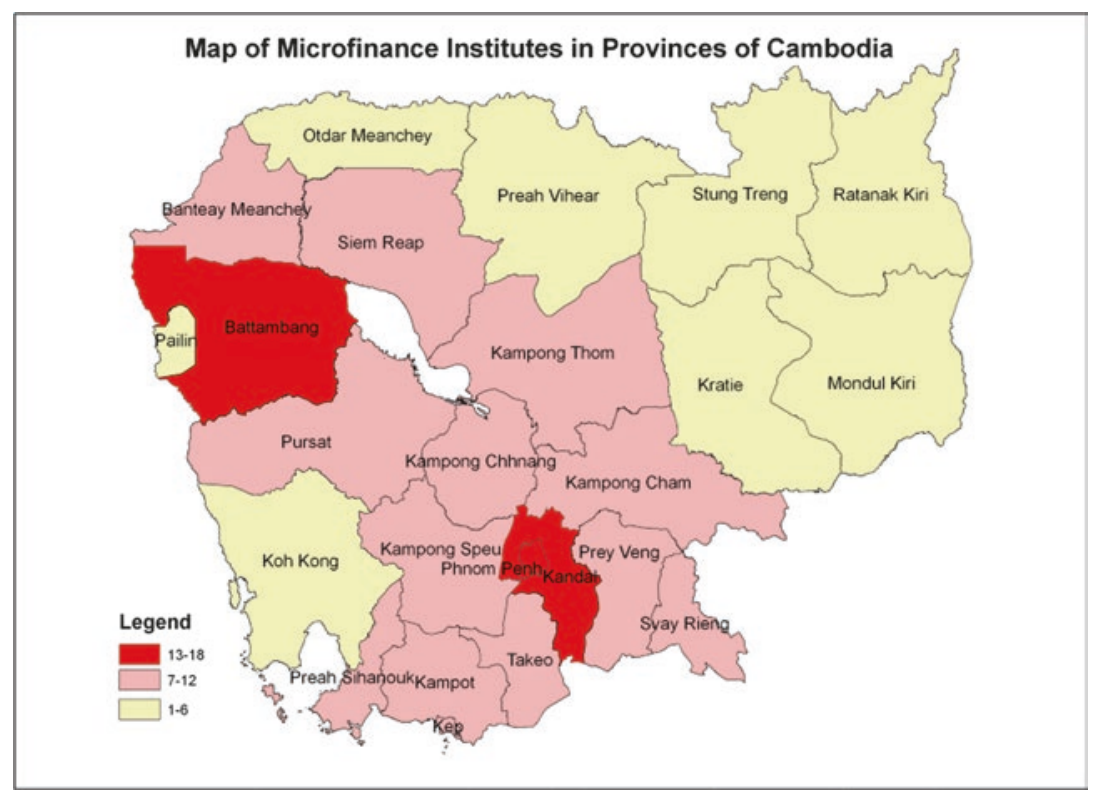

Fig. 15.2 Number of MFIs by province, 2011. (Source: Constructed from CMA data) 


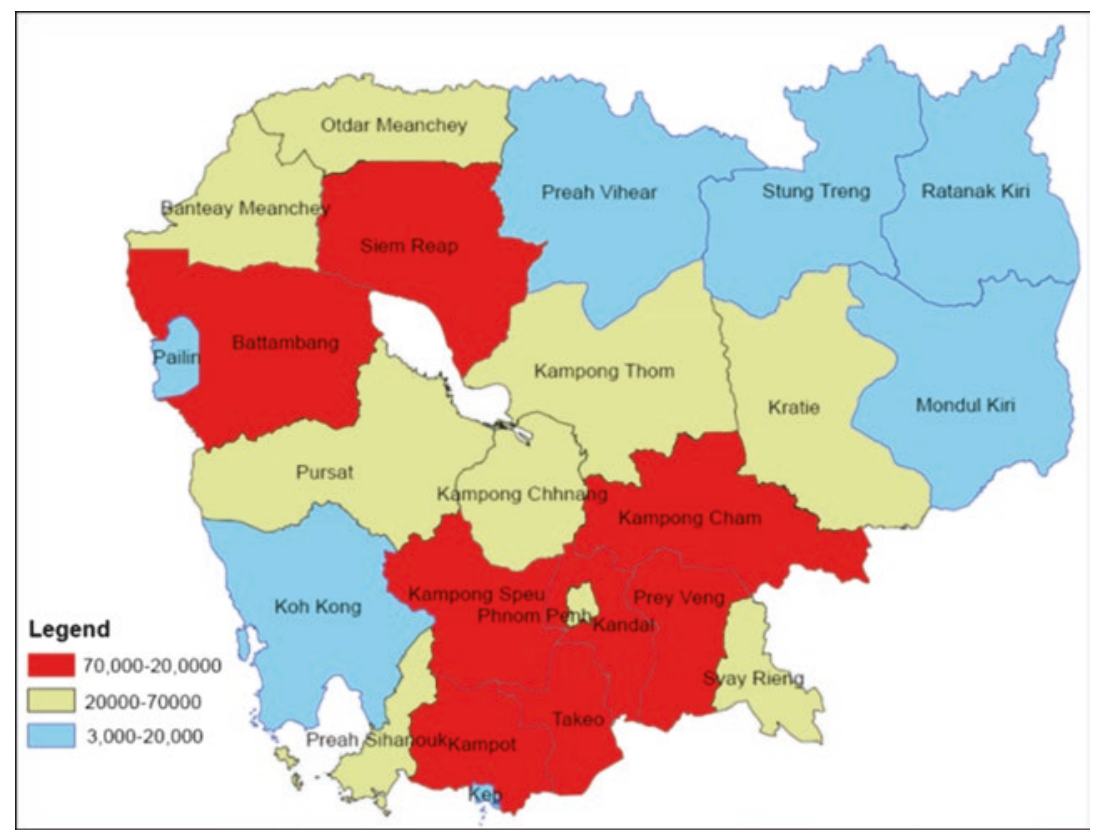

Fig. 15.3 Number of MFI borrowers by province, 2011. (Source: Constructed from CMA data)

province was associated with agricultural and economic growth in that province. For example, the highest numbers of borrowers in 2011 were in the provinces with the fastest rates of agricultural growth, such as Battambang, Kampong Cham, and Takeo (Ovesen et al. 2012). A province like Siem Reap also had a high number of both borrowers and MFIs because of economic diversification through tourism. Hence large numbers of poor and very poor households in less developed provinces were still not able to access financial services, preventing them from improving their livelihoods and gaining greater benefits from economic development.

Economic growth and macroeconomic stability have been important stimulants for the development of the rural credit sector. First, the change towards a liberal economic environment enabled the development of MFI institutions. Second, the development of rural infrastructure such as roads and irrigation improved access to farm inputs, supportive rural policy, and expanding markets have stimulated agricultural 
and rural development and hence the demand for credit. Third, increased competition among MFIs led to a reduction in monthly interest rates from $5-6 \%$ to $2.5-5 \%$, allowing more people to borrow. Fourth, MFIs have progressively offered more flexible mechanisms such as different loan types and different means of repayment.

\section{Credit Provision and Utilisation in Takeo}

\section{Overview}

Both formal and informal credit were available in Takeo. Ten MFIs operated in all ten districts. The number of MFI borrowers totalled 116,695 in 2011, but as Figs. 15.4 and 15.5 illustrate, the distribution between districts varied widely, reflecting population density, economic diversification, and agricultural production (CMA 2011; Ovesen et al. 2012). Most farming in the province was subsistence-oriented. Most households did not use credit to invest in agriculture; instead, they took out loans for other purposes such as small business expansion, wage migration, and buying household assets. Around 70\% of borrowers preferred small loans of USD 250-1500. Bati and Tram Kak Districts had the highest number of borrowers.

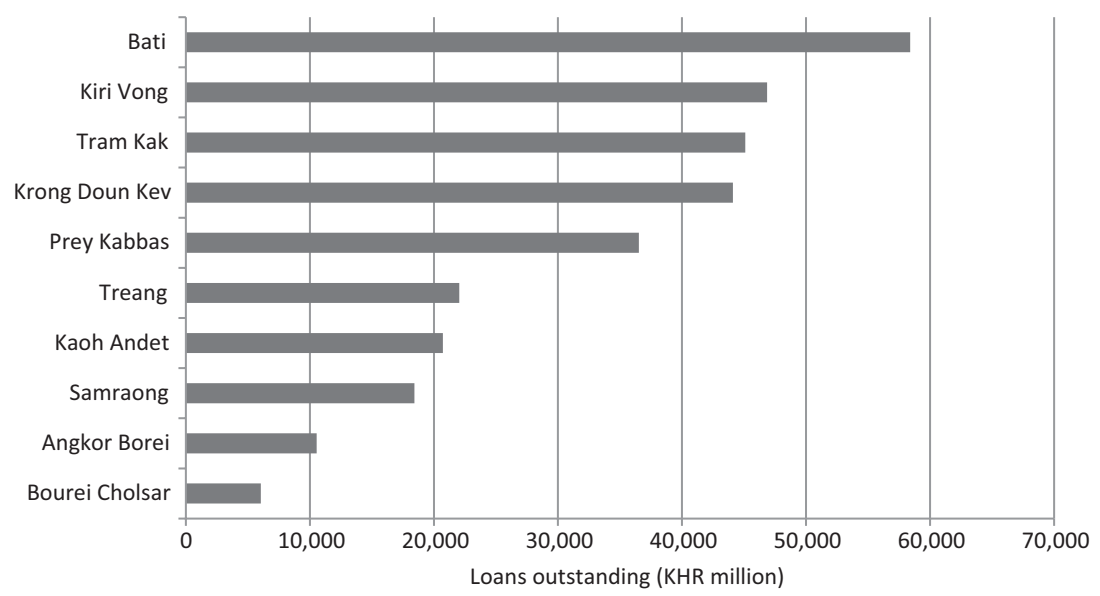

Fig. 15.4 Total amount of MFI outstanding loans in Takeo in 2011 by district (KHR million). (Note: USD 1 = KHR 4000; Source: constructed from CMA data) 


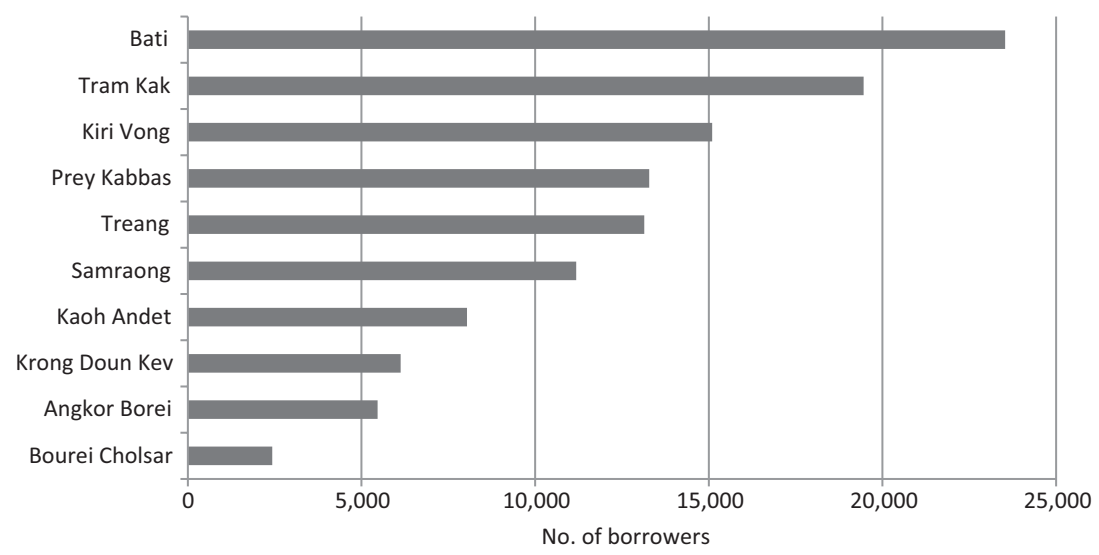

Fig. 15.5 Number of MFI borrowers in Takeo in 2011 by district. (Note: USD l = KHR 4000; Source: constructed from CMA data)

However, the greatest demand for agricultural loans was from commercial rice producers in Angkor Borei, Bourei Cholsar, Kiri Vong, and Kaoh Andet districts, which were reported to have the highest number of farmers accessing credit for irrigated DS rice production.

\section{Credit Access by Type of Rice Farmer}

Access to credit varied between different types of farmers - the subsistenceoriented farmer, the semi-commercial farmer, and the commercial farmer. The pattern of access to loans among these three types is illustrated in Fig. 15.6. It can be seen that the three main sources of credit were merchants/traders, moneylenders, and MFIs. The subsistence and semicommercial farmers used all three sources, though to differing degrees, as well as traditional rotating savings and credit associations (ROSCAs). The commercial farmers used only MFIs. It is interesting to note that the MFIs also provided credit to merchants, traders, and moneylenders, reflecting the overall importance of MFIs in the supply of credit in the province.

(a) Subsistence farmers. The main source of finance for small, subsistenceoriented farmers was the local moneylender. Loans were usually small, ranging from USD 250 to USD 1000, and the interest rate was around $10 \%$ per month, which was more than three times higher than the rate charged by MFIs. Interestingly, these loans were mostly not used for 


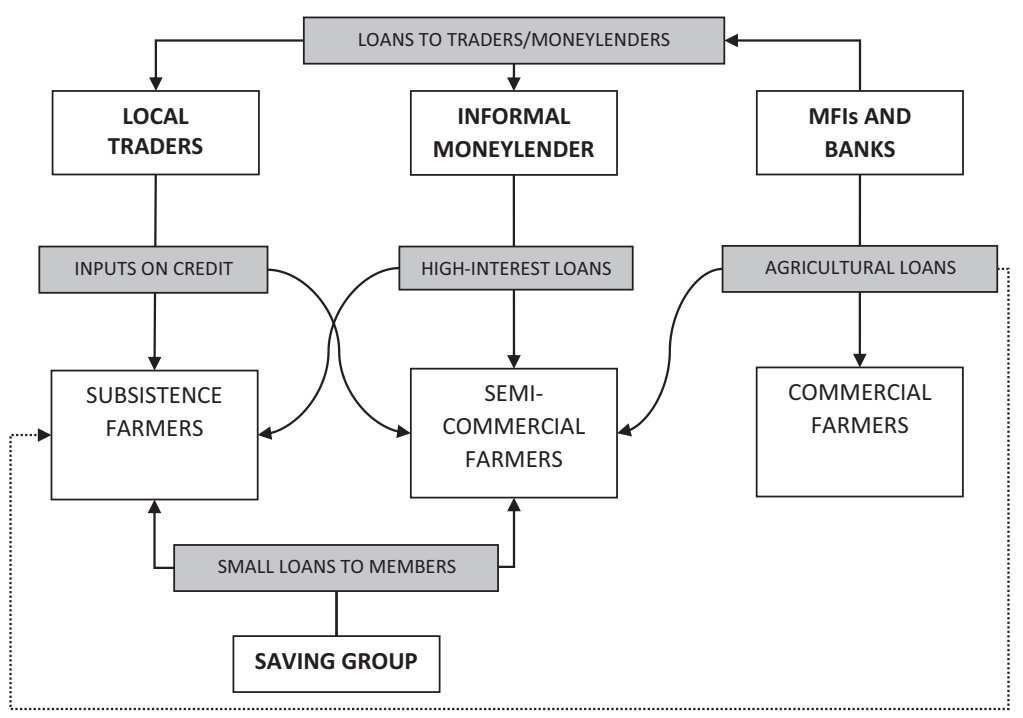

Fig. 15.6 Pattern of access to credit by type of rice farmer. (Source: Field interviews)

agriculture as such but for expanding and diversifying income sources through raising animals, migrating to work in industrial plantations in Kratie or Ratanakiri to the north, or opening a small business. They were also used for consumption expenditure and house construction. Subsistence farmers preferred to use labour-intensive production methods which required less use of purchased or hired inputs, thus minimising their demand for formal loans. However, agricultural inputs (fertiliser, pesticides) were bought on credit from local input suppliers, to be repaid after harvest.

These informal sources of credit required no collateral, were flexible, and could easily be accessed by farmers, explaining why they have long been favoured by small farmers, despite higher interest rates than for MFI loans. Strong social capital within the community underpinned access to credit for subsistence farmers. Moneylenders were usually located in the same village and were well-informed about the borrower's situation. Subsistence farmers in a group discussion in Chumpu Prik Village, Prey Kabas District, expressed their preference as follows: "We prefer to borrow money from a moneylender in the village because it is fast and flexible. We 
can take a loan whenever we want and repay the loan after harvesting or when we get money from other jobs. It is not like getting money from angkar (MFIs) which require us to fill in various forms; they also need collateral and we cannot repay early."

There were several other reasons that formal credit was less accessible to subsistence farmers. In Takeo, $57 \%$ of farmers had less than 1 ha, hence had insufficient collateral for a medium-sized loan. Moreover, subsistence rice farming was still highly vulnerable to production failures due to unpredictable weather conditions and pest outbreaks, hence financing it was highly risky. In fact, small farmers were usually not targeted by MFIs for agricultural loans but for loans to diversify their income-earning activities (hence the dotted line in Fig. 15.6). Interviews with MFI officers indicated that small farmers' lack of skill and knowledge on how to use credit properly was the major factor limiting their access to formal credit. In difficult circumstances, poor households often used loans not only for the productive purpose specified but to cope with shocks or refinance a previous loan, risking their ability to repay the new loan. As a result, many farmers were trapped in a debt cycle.

Group lending was another model for credit provision that was designed to improve access to finance for farmers without collateral, using the group guarantee mechanism. However, high levels of risk made it difficult for small farmers to take out a group loan. Small farmers were extremely vulnerable to both idiosyncratic and covariant shocks. Idiosyncratic shocks were those specific to a given household, including illness, localised crop damage, business failure, and loss of income from employment. However, covariant shocks affected all farmers in a group. Given limited irrigation facilities, drought was the most common covariant shock affecting farmers. Given this high degree of shared vulnerability among small farmers, group loans were less likely to give them access to formal credit for farming. Even with no collateral requirement, poor farmers found it hard to form a group or choose the group's representative who would be responsible for the members' repayments. Farmers in Prey Kdouch Village, Tramkak District, commented: "It is so difficult for us to form a group to access a loan. All of us face such hardship in our living. We simply cannot form a group [to take a] loan because we do not trust our group members to be able to pay back their loan on time. It may be difficult for us if they don't."

Traditional self-help groups in the form of rotating saving and loan associations offered some kind of financial support to farmers. However, the capital in each saving group was small, ranging from KHR 2 million 
(USD 500) to KHR 6 million (USD 1500). Group members could access loans up to KHR 400,000 (USD 100). Most loans were used for daily consumption or to cope with shocks but not for investment in agriculture or business. This type of loan contributed to risk-coping ability but was not likely to contribute to increased productivity.

In sum, subsistence farmers were largely excluded from formal agricultural credit. The risk of production failure, the lack of collateral, the high degree of covariant risk, and the frequent diversion of loans to nonproductive uses inhibited poor farmers from applying for agricultural loans and discouraged MFIs from approving them. In this context, informal credit continued to play an important role in providing the short-term capital needs of this type of farm household.

(b) Semi-commercial farmers. This type of farmer produced rice for both household consumption and sale. This was possible because they cultivated both WS and DS rice, with the DS crop produced exclusively for the market. A typical enterprise budget for both seasons is presented in Table 15.2.

For the WS crop, farmers used family labour for most activities. The rice was largely unirrigated, and little machinery was used as the farms were mostly not accessible to tractors. Long-duration rice varieties were

Table 15.2 Enterprise budget for semi-commercial rice farming

\begin{tabular}{lllllll}
\hline Budget item & \multicolumn{7}{c}{ Wet-season rice } & \multicolumn{5}{l}{ Dry-season rice } \\
\cline { 2 - 7 } & $\begin{array}{l}\text { Value/ha } \\
\left(\text { KHR } \times 10^{3}\right)\end{array}$ & $\begin{array}{l}\text { \% of } \\
\text { costs }\end{array}$ & $\begin{array}{l}\text { \% of } \\
\text { revenue }\end{array}$ & $\begin{array}{l}\text { Value/ha } \\
\left(\text { KHR } \times 10^{3}\right)\end{array}$ & $\begin{array}{l}\text { \% of } \\
\text { costs }\end{array}$ & $\begin{array}{l}\text { \% of } \\
\text { revenue }\end{array}$ \\
\hline $\begin{array}{l}\text { Land } \\
\text { preparation }\end{array}$ & 160 & 13 & 7 & 360 & 11 & 6 \\
$\begin{array}{l}\text { Seed } \\
\text { Hired labour }\end{array}$ & 350 & 6 & 3 & 360 & 11 & 6 \\
$\begin{array}{l}\text { Chemical } \\
\text { fertiliser }\end{array}$ & 250 & 30 & 15 & 0 & 0 & 0 \\
$\begin{array}{l}\text { Pesticide } \\
\text { Irrigation }\end{array}$ & 0 & 21 & 11 & 1290 & 37 & 23 \\
$\begin{array}{l}\text { Harvesting/ } \\
\text { threshing }\end{array}$ & 60 & 0 & 0 & 500 & 15 & 9 \\
$\begin{array}{l}\text { Total costs } \\
\text { Gross revenue }\end{array}$ & 1190 & 25 & 13 & 640 & 19 & 11 \\
Gross margin & 1110 & 5 & 3 & 280 & 7 & 6 \\
\hline
\end{tabular}

Source: Field interviews 
planted, and chemical fertiliser application averaged about $100 \mathrm{~kg} / \mathrm{ha}$. Valuing the output at the market price, the gross margin was about KHR 1.1 million/ha (USD 275). Farmers preferred to access inputs such as fertiliser from local merchants on credit, claiming that this service was readily available and they could repay the credit after harvest (Fig. 15.6). The interest rate for this credit was 3-5\% per month. ${ }^{2}$ The WS rice harvest was mainly for household consumption. However, farmers sometimes sold part of the WS crop if the DS crop had been less profitable or if they needed to repay credit or loans. They often experienced a shortage of rice (and cash) for around two-three months before the WS harvest.

For the DS crop, expenditure on inputs was three times higher, especially due to higher use of fertilisers, which made up $37 \%$ of costs, but also because of expenditure on mechanised land preparation, irrigation, pesticides, and threshing (Table 15.2). However, higher yield and price meant that the gross margin was KHR 2.2 million/ha (USD 550), about double the return for the WS crop. The higher costs and returns meant that farmers sought both formal and informal credit for their production expenditure. Though total costs were about KHR 3 million/ha, loans were around KHR 1-2 million (USD 250-500). Given their small landholdings (hence limited collateral), most farmers could only obtain loans of around KHR I million, suggesting that the formal lenders were imposing capital rationing on small farmers. Given the excess demand for credit, some moneylenders took loans from MFIs at 3\% interest and re-lent this to farmers (without collateral but with other ties) at 5-7\% interest (Fig. 15.6).

As with WS rice, farmers also bought inputs on credit in the DS, incurring up to $5 \%$ per month in implicit interest to be paid along with the principal after harvest. However, DS gross margins were highly vulnerable to fluctuations in the price as farmers were mainly dependent on the Vietnam market. In 2012, for example, the rice price quickly fell from KHR $1200 / \mathrm{kg}$ to $700 / \mathrm{kg}$ (from USD 0.30 to 0.18 ). In these circumstances, some farmers borrowed additional money from the MFIs to repay the local input merchants, thus risking the loss of their land and other household assets to meet their production commitments. If production failure (e.g., due to a pest outbreak) coincided with falling prices, the farmers would have been plunged into a debt crisis.

In semi-commercial rice farming, farmers earned only modest income from their production due to the high cost of production, high interest on loans, and reduction in the market price of rice. In group discussions, farmers maintained that this level of income could only support a modest 
lifestyle and severely limited their ability to cope with shocks. Thus their livelihoods remained highly vulnerable. As group participants in Pich Sar Commune, Koh Andeth District, expressed it: "After harvesting we have to pay for chemical fertilisers, pesticides, machinery hire-we pay for almost everything in rice production. We earn around 30-40 meun riel [USD 75-100] per kong [0.13 ha]. ${ }^{3}$ We have been trying very hard each year just to make a profit." Another group of farmers in Pich Sar Commune, Koh Andeth District, commented: "Money from angkar (MFIs) helps only those who are already rich, because they have multiple occupations and constant income to pay back the interest. Not like us who depend only on rice farming. We cannot borrow money like them because we cannot even pay the interest. Rice farming is too risky now, everything for production is expensive but when we sell our rice the price is too cheap."

(c) Commercial farmers. Commercial farmers cultivated only DS rice for the market, using large areas of land that were flooded in the WS, adding to the fertility of the soil and reducing the fertiliser requirement for DS production. Interviews with rice farmers in Khmol Village, Kamnab Commune, Kirivong District, indicated that around $50 \%$ of farmers owned around 5 ha of paddy land, 30\% owned 3-4 ha, and only $20 \%$ owned 1-2 ha. Farmers used IR varieties, given their high yield and market potential. The average yield was $6 \mathrm{t} / \mathrm{ha}$, significantly more than semicommercial DS rice. Production costs were much the same as for the semicommercial farmers in the DS as the lower fertiliser costs were offset by higher pesticide use and mechanisation (Table 15.3). The total cost of production was KHR 3.1 million (USD 775) per hectare, of which $57 \%$

Table 15.3 Enterprise budget for commercial dry-season rice farming

\begin{tabular}{lrll}
\hline Budget item & Value/ha $\left(\mathrm{KHR} \times 10^{3}\right)$ & \% of costs & \% of revenue \\
\hline Land preparation & 280 & 9 & 6 \\
Seed & 210 & 7 & 4 \\
Hired labour & 0 & 0 & 0 \\
Chemical fertiliser & 460 & 15 & 10 \\
Pesticide & 1300 & 42 & 27 \\
Irrigation & 560 & 18 & 12 \\
Harvesting/threshing & 280 & 9 & 6 \\
Total costs & 3090 & 100 & 65 \\
Gross revenue & 4800 & & 100 \\
Gross margin & 1710 & & 35
\end{tabular}


was for expenditure on agrochemicals. Land preparation and harvesting involved hiring mechanised services (18\% of costs) and irrigation costs accounted for a further $18 \%$. Despite higher yields, gross revenue was lower than in Table 15.2 because of a fall in price, hence the gross margin was KHR 1.7 million (USD 425 ) per hectare. However, the larger scale of production meant that total profits were substantial.

Commercial rice farmers took loans from MFIs to cover their entire production expenditure (Fig. 15.6), though some of the large landholders used their own capital for some or all of their costs. Having large and fertile landholdings to offer as collateral plus a profitable enterprise gave commercial farmers ready access to agricultural credit. Loans of USD 1000-1500 were common among farmers with 3-4 ha of DS paddy land, four-six times as much as the semi-commercial farmers. Given the urgency to repay their loans and avoid incurring further interest charges, farmers sold their paddy immediately after harvest, preventing them from obtaining a higher price during the wet season. ${ }^{4}$ Commercial rice production also faced price fluctuations, pest hazards, and rising input costs, which threatened to reduce gross margins and hence the ability of farmers to repay their loans to the MFIs. Farmers in Khmol Village, Kirivong District, recounted: "Before we cultivated late-season [recession] rice, the yield was low but we were never trapped in debt like today. We sold our rice only when we needed money or when the price of rice was high ... Now we cultivate dry-season rice, the yield is high but we also pay for everything ... The costs of fertilizers, pesticides, and machinery use keep increasing year by year ... We are afraid there might be one day that we cannot repay our loan to angkar (MFI)." Despite these concerns, credit for rice farming seemed to be much more viable when used by commercial farmers. Access to credit worked smoothly where there was a favourable natural endowment, good access to inputs, supporting physical infrastructure, and a ready market for the output.

\section{Impact of Credit on Rice Farmers' Liveliboods}

In group discussions with the three types of rice farmers, opinions were sought regarding the positive and negative impacts of credit on household livelihoods.

For subsistence-oriented farmers, the chances of successfully using loans for agricultural production were slim. Subsistence rice-farming systems suffered from lack of collateral, lack of supporting infrastructure, 
high input costs, considerable risk and vulnerability, limited income diversification, and a fluctuating rice price. Many MFIs avoided providing agricultural loans to small subsistence farmers. The farmers themselves rarely sought agricultural loans but instead focused on loans for more productive purposes such as animal raising, trading, operating small businesses, and migrating to work in industrial plantations. Access to loans for these purposes helped to diversify their income sources. Farmers felt that, to be able to use agricultural loans successfully, they needed to have at least two income sources from non-farm activities, otherwise they could not repay the loans to the MFIs. Farmers who obtained loans for investing in off-farm sources of income reported that their livelihoods were improved by having diverse income sources, better food security, and increased household assets. This suggests that access to credit enabled the adoption of more profitable income-generating activities for subsistence farmers, leading to a gradual improvement in livelihoods. Farmers in Prey Kdouch Village, Tramkak District, emphasised this point: "It is not always true that loans from angkar (MFIs) cause people in the community to become even poorer ... It depends on the way people use the loans. If they borrow money to buy a motorbike, or spend carelessly, they will certainly become poorer. Many people took a loan for pig raising, collecting rice to sell, or starting a small business, and they were successful. They have better lives now."

The impacts of credit on semi-commercialised farmers were uncertain. These farmers depended solely on WS and DS rice production for income. Without other livelihood activities, they were vulnerable to crop failure. The increasing number of MFIs operating in the province enabled farmers to access capital to invest in rice farming, transforming their production systems from subsistence to semi-commercial farming. Most farmers accessed loans from multiple MFIs. The impact of this use of credit could be positive or negative depending on farm profit, which was largely determined by weather conditions and the price of rice. Farmers felt they could be profitable if the price of rice was KHR $1200 / \mathrm{kg}$ or above. With this price, farmers could repay their loans and pay for the fertilisers and pesticides used during the season. In this scenario, income from rice farming contributed to increased household well-being. However, in 2012 , the rice price was about $\mathrm{KHR} 700 / \mathrm{kg}$, reducing the rice gross margin to KHR 1.3 million (USD 328) per ha. Many farmers fell deeper into debt because of the low price. The common coping strategies used 
were reducing household consumption of both food and non-food items and, in some cases, selling household assets to repay debts.

Credit for commercial rice farmers clearly contributed to improved household livelihoods. Farmers reported increasing rice yields from around $3 \mathrm{t} / \mathrm{h}$ a to almost $6 \mathrm{t} / \mathrm{ha}$, largely due to access to capital, irrigation, mechanisation, and an export market. The presence of MFIs contributed to the acceleration of agricultural commercialisation in these areas. Farmers also reported increased household assets, including better housing and more machinery, better education for their children, and greater food security. However, the increasing cost of production and fluctuations in the price of rice may reduce farmers' incomes and capacity to service loans. In addition, there were reports of more frequent and extensive pest damage and increasing pollution due to the intensive use of pesticides. These trends could undermine the productivity of the farming systems and affect welfare directly through impacts on health.

\section{Conclusion}

The study found several challenges affecting viable credit use by rice farmers in Takeo Province. High and increasing farm input costs, the low quality of fertilisers, and the rising cost of mechanisation due to the price of fuel continued to hinder long-term agricultural growth, not just in rice production. While these trends implied greater capital needs, hence increased demand for credit, the squeeze on farm profits was reducing the viability of agricultural loans, especially for small farmers engaged primarily in rice production. The lack of a formal land title to use as collateral also remained a barrier to credit use for many farmers. The Land Management and Administration Project (LMAP) has accelerated the process of issuing rural land titles, but the needs of small farmers must be further prioritised.

The need to ensure high repayment rates by carefully assessing potential clients meant that MFIs effectively screened out poor farmers with little collateral and high vulnerability. Nevertheless, poor farmers often resorted to loans from formal and informal sources when subject to livelihood shocks, despite the high risk of falling even deeper into indebtedness. Some MFIs such as CREDIT and Vision Fund had developed a special loan package (subsidised by donors) for this category of farmers. Increased investment in the government's social protection programme would also help reduce the vulnerability of the poor and protect them from falling into burdensome debt. 
A challenge facing all farmers was the high interest rates for formal credit. At the time of the study, MFIs were charging around 30\% p.a. (2.5\% p.m.) to cover operational costs and maintain financial sustainability. Many depended on outside sources of capital, while low domestic savings remained a barrier to lowering the interest rate. However, MFIs have reduced interest rates over time due to increasing competition and local saving. MFI representatives interviewed claimed to be aiming for an interest rate of $1 \%$ p.m. In 2017, the National Bank of Cambodia (NBC) introduced a ceiling of $18 \%$ p.a. for MFIs, or $1.5 \%$ p.m. Some farmers have recently reported paying interest at rates less than this, though not yet as low as 1\% (Moeun Nhean 2017).

Demonstrating improved cultivation methods to farmers could help increase productivity and farm income and make farm investment more viable. With training in business skills, farmers would be better able to use MFI loans successfully, whether for rice farming or other livelihood activities. Rural development NGOs could better integrate these measures into their extension programmes. Long prioritised by the government to improve productivity and reduce production and market risks, further investment in infrastructure is also needed to help transform subsistence farming. Greater private sector involvement in the rice sector through contract farming may also be a means of facilitating and financing smallholder development (see Chap. 17).

Increasing regional demand for rice plus government policy to promote rice exports is driving growth of the commercial rice sector. Government efforts to improve agricultural infrastructure, such as irrigation facilities and the road network, and increased private sector investment in rice milling and storage will boost production, facilitate trade, stabilise market demand for rice, and help smooth rice price fluctuations. All these will increase the importance of small-scale agricultural credit. Provided the vulnerability of poor farmers is addressed in the ways suggested above, this expansion of credit use will have a largely positive impact on rural livelihoods.

\section{Notes}

1. Moeun (2017) quotes a villager from Kandal Province who said: "Most of my villagers know that MFIs are part of the private sector, but we have called them Angkar since a very long time ago." Angkar, meaning "organisation”, was the term used in the Khmer Rouge era to refer to "the government". 
2. Urea cost about KHR 135,000 (USD 34) per sack if paid for in cash. If a farmer bought the urea on credit, the cost increased to KHR 165,000 (USD 41). However, the farmer could obtain as much urea as he needed and was only required to repay the merchant when the harvest was finished. Normally, the period for wet-season rice production was six months. This implied a monthly interest of about $3 \%$ if the urea was bought at the start of the season or $5 \%$ if it was bought four months before harvest.

3. This works out to be about USD $580-770$ per ha, presumably referring to gross revenue (cf. Table 15.2).

4. Harvesting was also increasingly undertaken by Vietnamese traders using combine harvesters; hence, the harvested paddy was of high moisture content and was transported directly to rice mills in Vietnam with drying capacity.

\section{REFERENCES}

ACI, 2005. Final Report for the Cambodia Agrarian Structure Study. Prepared for the Ministry of Agriculture, Forestry and Fisheries, Royal Government of Cambodia, the World Bank, the Canadian International Development Agency (CIDA) and the Government of Germany/Gesellschaft für Technische Zusammenarbeit (GTZ). Bethesda, MA: Agrifood Consulting International.

ADB, 2001. Financial Sector Blueprint for 2001-2010. Phnom Penh: Asian Development Bank.

CMA, 2011. Microfinance Information Exchange. Cambodia Microfinance Association. Available at https://cma-network.org/en/microfinanceinformation-exchange.

CMA, 2015. Annual Report 2014. Phnom Penh: Cambodia Microfinance Association.

CMA, 2017. Microfinance Information Exchange. Cambodia Microfinance Association. Available at https://cma-network.org/en/microfinance-infor mation-exchange.

Moeun Nhean, 2017. Misuse of MFI loans leaves locals in debt. Phnom Penh Post, 21 March 2017.

Ovesen, J., Trankell, I. B., Heng, K., and Sochoeun, C., 2012. Rice Farming and Microcredit in Takeo. Phnom Penh: Uppsala University and Intean Poalroath Rongroeurng Ltd.

Phlong, P., 2009. Informal Credit Systems in Cambodia. Master's Thesis, Northern Illinois University, DeKalb, Illinois.

World Bank, 2007. Sharing Growth: Equity and Development in Cambodia. Phnom Penh: World Bank for the Cambodia Development Cooperation Forum. 
Open Access This chapter is licensed under the terms of the Creative Commons Attribution 4.0 International License (http://creativecommons.org/licenses/ by $/ 4.0 /)$, which permits use, sharing, adaptation, distribution and reproduction in any medium or format, as long as you give appropriate credit to the original author(s) and the source, provide a link to the Creative Commons licence and indicate if changes were made.

The images or other third party material in this chapter are included in the chapter's Creative Commons licence, unless indicated otherwise in a credit line to the material. If material is not included in the chapter's Creative Commons licence and your intended use is not permitted by statutory regulation or exceeds the permitted use, you will need to obtain permission directly from the copyright holder.

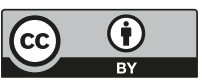

